\title{
Role of tyrosine kinases in bladder cancer progression: an overview
}

\author{
Amir Sadra Zangouei ${ }^{1}$, Amir Hossein Barjasteh ${ }^{1}$, Hamid Reza Rahimi ${ }^{2}$, Majid Mojarrad ${ }^{2}$ and Meysam Moghbeli ${ }^{2^{*}}$ (D)
}

\begin{abstract}
Background: Bladder cancer (BCa) is a frequent urothelial malignancy with a high ratio of morbidity and mortality. Various genetic and environmental factors are involved in BCa progression. Since, majority of BCa cases are diagnosed after macroscopic clinical symptoms, it is required to find efficient markers for the early detection. Receptor tyrosine-kinases (RTKs) and non-receptor tyrosine-kinases (nRTKs) have pivotal roles in various cellular processes such as growth, migration, differentiation, and metabolism through different signaling pathways. Tyrosine-kinase deregulations are observed during tumor progressions via mutations, amplification, and chromosomal abnormalities which introduces these factors as important candidates of anti-cancer therapies.

Main body: For the first time in present review we have summarized all of the reported tyrosine-kinases which have been significantly associated with the clinicopathological features of BCa patients.

Conclusions: This review highlights the importance of tyrosine-kinases as critical markers in early detection and therapeutic purposes among BCa patients and clarifies the molecular biology of tyrosine-kinases during BCa progression and metastasis.
\end{abstract}

Keywords: Bladder cancer, Tyrosine-kinase, Diagnosis, Targeted therapy, Panel marker

\section{Background}

Bladder cancer $(\mathrm{BCa})$ is the 10th most frequent malignancy worldwide [1], and the fourth most prevalent malignancy among American males with $7 \%$ of all cancer cases [2]. There are an estimated 62,100 new BCa cases and 13,050 deaths annually among American males [2]. Approximately 430,000 new cases of $\mathrm{BCa}$ and 150,000 deaths were reported in 2012 worldwide [3]. The highest incidence rates were observed in both sexes in European countries and Northern America, while the Lebanese females had the highest rates in the world [1]. There is a correlation between age and higher risk of $\mathrm{BCa}$ progression [4]. The $\mathrm{BCa}$ is also three to four times more frequent among males compared with females [5]. The prevalence of BCa can be associated with environmental and genetic determinants,

\footnotetext{
*Correspondence: moghbelim@mums.ac.ir; Meysam_moghbeli@yahoo.com ${ }^{2}$ Department of Medical Genetics and Molecular Medicine, School of Medicine, Mashhad University of Medical Sciences, Mashhad, Iran Full list of author information is available at the end of the article
}

which are different among racial/ethnic groups [6, 7]. Based on histopathologic features of tumor cells, there are three main types of $\mathrm{BCa}$ including: transitional cell carcinoma, squamous cell carcinoma, and adenocarcinoma, which account for $90,5 \%$, and less than $2 \%$ of $\mathrm{BCa}$ cases, respectively [8]. Non-muscle-invasive bladder cancer (NMIBC) or superficial bladder cancer which constitutes about $75 \%$ of newly diagnosed cases is confined to the lamina propria without invasion to underlying muscle tissues. Muscleinvasive bladder cancer (MIBC) involves about $25 \%$ of cases that has invasion to the muscularis propria and perivesical fat [9]. There are various treatment options for the $\mathrm{BCa}$ including radical cystectomy, transurethral resection, chemotherapy, radiotherapy, immunotherapy, and targeted therapies against specific signaling proteins $[10,11]$. Over the past decades, mutations in kinases have been shown to be engaged in bladder malignancies [12]. Protein kinases are a large family of proteins with more than 500 members which are encoded by $\sim 2 \%$ of all human genome. Their

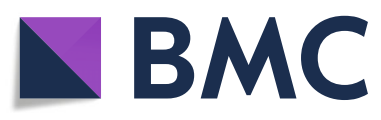

(C) The Author(s). 2020 Open Access This article is licensed under a Creative Commons Attribution 4.0 International License, which permits use, sharing, adaptation, distribution and reproduction in any medium or format, as long as you give appropriate credit to the original author(s) and the source, provide a link to the Creative Commons licence, and indicate if changes were made. The images or other third party material in this article are included in the article's Creative Commons licence, unless indicated otherwise in a credit line to the material. If material is not included in the article's Creative Commons licence and your intended use is not permitted by statutory regulation or exceeds the permitted use, you will need to obtain permission directly from the copyright holder. To view a copy of this licence, visit http://creativecommons.org/licenses/by/4.0/ The Creative Commons Public Domain Dedication waiver (http://creativecommons.org/publicdomain/zero/1.0/) applies to the data made available in this article, unless otherwise stated in a credit line to the data. 
main function is the phosphorylation of definite amino acids on key proteins involved in critical cellular mechanisms such as proliferation, differentiation, survival, and apoptosis $[13,14]$. As these cellular processes are of paramount importance, the enzymatic function of these kinases is strictly regulated [15]. Tyrosine-kinases (TKs) are one of the major types of protein kinases which induce phosphorylation of tyrosine residues on a substrate protein. TKs are found in nuclear and membrane-bound forms as well as transmembrane receptors [16]. There are about ninety TKs in human genome which are involved in various cellular processes such as differentiation, metabolism, motility, and proliferation $[17,18]$. Receptor tyrosine-kinases are up regulated in various tumors and are considered to be potential oncogenes involved in cancer initiation and development $[19,20]$. Therefore, targeting these oncogenes and inhibiting their expression may result in good clinical outcomes [21]. The majority of TKs share a similar structure consisting of a conserved catalytic domain and regulatory domains which are located within or outside the catalytic domain. The catalytic domain contains $250-300$ amino acids in 12 conserved subdomains and catalyzes the transfer of a phosphate group from ATP to the tyrosine residue. Activation and recruitment of downstream signaling pathways occur following this phosphorylation. Regulatory domains regulate the kinase activity and its localization in response to different stimuli [22, 23]. Studies have shown oncogenic characteristics of TKs [24]. Dysregulation of TKs by gain of function mutations or over expression occurs in various malignancies like $\mathrm{BCa}$ which accelerates tumor proliferation and progression $[25,26]$. Therefore, inhibiting signaling pathways of different tyrosine kinases using tyrosinekinase inhibitors (TKIs) have been reported as efficient method of tumor targeted therapies [27-29]. BCa patients are diagnosed with a broad range of tumor behaviors from low grade and stage tumors with less aggressiveness to tumors with advanced grade, stage, and distant metastasis. Clinicopathological features are commonly used to predict tumor growth, recurrence, and patient's survival. However, the gene expression profiling and molecular pathway analysis have gained growing attention as a novel and promising methods for the prediction of disease course and prognosis in $\mathrm{BCa}$ patients $[7,30,31]$. Since, tyrosinekinases have essential roles in $\mathrm{BCa}$ progression, in present review we have summarized all of the studies which have been assessed the role of tyrosine-kinases in $\mathrm{BCa}$ patients in the world (Table 1).

\section{Main text}

\section{RTK class I}

The ERBB family includes ERBB1 (EGFR), ERBB2 (HER2), ERBB3 (HER3), and ERBB4 (HER4) that are the class I receptors of tyrosine-kinases (RTKs). The HER2/ neu is involved in transduction of mitogen signals through activation of various signaling pathways such as MAP kinase, PI3 kinase, and MYC [104, 105]. The prevalence of HER2/neu over expression in $\mathrm{BCa}$ is one of the most elevated among human malignancies, with a range of 9 to $34 \%$ of examined cases [106, 107]. HER2 up regulation is mainly due to gene amplification which triggers intracellular pathways that promote cell proliferation, migration, and aggressiveness of tumor cells [105, 108]. Various studies have been reported that there were significant associations between tumor grade and HER-2 up regulation or gene amplification among different population of $\mathrm{BCa}$ patients [32-36]. The pT2 tumors have a considerable amount of mutations compared with $\mathrm{pTa} / \mathrm{Ti}$ tumors [109]. Protein up regulation and gene amplification of HER2/neu occur more frequently in pT2 tumors in comparison with $\mathrm{pTa} / \mathrm{Ti}$ tumors which are correlated with a poor prognosis [107, 110-114]. A significant high frequency of chromosome 17 polysomy (97\%) and increased HER2/neu copy number (92\%) were also observed in a sample of BCa patients. Polysomy 17 and HER2/neu up regulation were frequent in G3 pT2 tumors [37]. Another study has been shown that there was HER2/neu abnormality in pT2 BCa tumors before muscle invasion. Polysomy 17 and HER2/neu amplification and up regulation were correlated with advanced disease. Therefore, the HER2/neu deregulation was observed before the muscle invasion [38]. A quarter of patients experiencing cystectomy and lymphadenectomy for NOM0 staged BCa showed lymph node metastases which resulted in death among two thirds of patients $[115,116]$. The chemotherapy is not efficient in metastasizing bladder malignancy, and new therapeutic modalities are required $[117,118]$. It has been observed that the HER2 amplification was significantly increased in urothelial bladder tumors with lymph node metastasis compared with initial tumors. HER2 amplification was also significantly associated with poor prognosis [39]. Another study has been shown that the patients with distant metastasis had co amplifications of HER2 and MYC in a sample of BCa cases. There was also a significant correlation between HER2 or MYC amplification and high-stage (pT4) tumor [40]. It has been shown that there were significant increased levels of HER2/neu expression in a sample of malignant $\mathrm{BCa}$ patients compared with benign and healthy cases. There were significant correlations between HER2/neu, ploidy, SPF, and lymph node involvement [41].

About $75 \%$ of BCa patients have NMIBC that can be limited to the mucosa (Ta) or carcinoma in situ (Tis) without stromal invasion or submucosal invasion (T1). Unsaturated fat synthase (FASN) down regulation induces apoptosis and represses tumor progression and metastasis [119]. FASN can be phosphorylated by mTOR and HER2/neu which is associated with its function and 
Table 1 All of the tyrosine kinases which have been significantly associated with clinicopathological features of BCa patients in the world

\begin{tabular}{|c|c|c|c|c|c|}
\hline Study & Year & Gene & Country & Sample & Results \\
\hline \multicolumn{6}{|l|}{ RTK class I } \\
\hline COOMBS [32] & 1993 & HER2 & UK & $\begin{array}{l}91 \text { tumor tissues } \\
99 \text { control tissues }\end{array}$ & Correlation between tumor grade and HER2 up regulation \\
\hline SIMON [33] & 2003 & HER2 & Switzerland & 2317 tumor tissues & Correlation between tumor grade and HER2 up regulation \\
\hline NADOUSHAN [34] & 2009 & HER2 & Iran & 75 patients & Correlation between tumor grade and HER2 up regulation \\
\hline Krüger [35] & 2002 & HER2 & Germany & 138 patients & Correlation between tumor grade and HER2 up regulation \\
\hline COOGAN [36] & 2004 & HER2 & USA & 54 patients & Correlation between tumor grade and HER2 up regulation \\
\hline LATIF [37] & 2004 & HER2 & UK & 75 patients & Increased HER2 copy number \\
\hline LATIF [38] & 2003 & HER2 & UK & 25 patients & Increased HER2 copy number \\
\hline $\begin{array}{l}\text { FLEISCHMANN } \\
{[39]}\end{array}$ & 2011 & HER2 & Switzerland & 150 patients & HER2 amplification was correlated with poor prognosis. \\
\hline HANSEL [40] & 2008 & HER2 & USA & 53 patients & HER2 amplification was correlated with high-stage (pT4). \\
\hline EISSA [41] & 2005 & HER2 & Egypt & 88 patients & HER2 expression was correlated with lymph node involvement. \\
\hline $\begin{array}{l}\text { ABDELRAHMAN } \\
{[42]}\end{array}$ & 2019 & HER2 & Egypt & 60 patients & HER2 up regulation was correlated RFS and PFS. \\
\hline DING [43] & 2015 & HER2 & China & 238 patients & $\begin{array}{l}\text { HER2 up regulation was correlated with advanced grade and } \\
\text { stage. }\end{array}$ \\
\hline BREYER [44] & 2016 & HER2 & Germany & 355 patients & $\begin{array}{l}\text { HER2 up regulation was correlated with advanced grade and } \\
\text { stage. }\end{array}$ \\
\hline ARIKAN [45] & 2015 & HER2 & Turkey & $\begin{array}{l}44 \text { patients } \\
40 \text { controls }\end{array}$ & HER2 urinary level was correlated with advanced grade. \\
\hline KOLLA [46] & 2008 & HER2 & India & 90 patients & $\begin{array}{l}\text { HER2 expression was correlated with advanced grade, stage, and } \\
\text { lymph node metastasis. }\end{array}$ \\
\hline KOGA [47] & 2011 & HER2 & Japan & 35 patients & HER2 up regulation was correlated with poor prognosis. \\
\hline INOUE [48] & 2014 & HER2 & Japan & 201 patients & HER2 up regulation was correlated with CRT resistance. \\
\hline SASAKI [49] & 2014 & HER2 & Japan & 171 patients & HER2 up regulation was correlated with grade and recurrence. \\
\hline KIM [50] & 2016 & HER2 & $\begin{array}{l}\text { South } \\
\text { Korea }\end{array}$ & 6 patients & HER2 protein up regulation and gene amplification \\
\hline MEMON [51] & 2004 & HER3, HER4 & Denmark & 88 patients & $\begin{array}{l}\text { HER3 and HER4 up regulations were correlated with good } \\
\text { prognosis. }\end{array}$ \\
\hline GUNES [52] & 2013 & $\begin{array}{l}\text { EGFR, HER2, } \\
\text { ErbB3, ErbB4 }\end{array}$ & Turkey & 40 patients & $\begin{array}{l}\text { EGFR and HER2 were down regulated and up regulated } \\
\text { respectively. }\end{array}$ \\
\hline Türkeri [53] & 1998 & EGFR & Turkey & 21 patients & EGFR expression was correlated with stage. \\
\hline POPOV [54] & 2004 & EGFR & France & $\begin{array}{l}113 \text { patients } \\
10 \text { controls }\end{array}$ & EGFR expression was correlated with survival. \\
\hline ARFAOUI [55] & 2016 & EGFR & Tunisia & $\begin{array}{l}64 \text { patients } \\
6 \text { controls }\end{array}$ & EGFR expression was correlated with grade and stage. \\
\hline BERGER [56] & 1987 & EGFR & UK & 31 patients & EGFR expression was correlated with grade and stage. \\
\hline KHALED [57] & 2009 & EGFR & Egypt & 59 patients & EGFR expression was correlated with stage and survival. \\
\hline LIPPONEN [58] & 1994 & EGFR, HER2 & Finland & 234 patients & EGFR expression was correlated with grade and aneuploidy. \\
\hline MEMON [59] & 2006 & $\begin{array}{l}\text { EGFR, HER2, } \\
\text { HER3, HER4 }\end{array}$ & Denmark & 88 patients & HER1-4 were correlated with poor prognosis. \\
\hline KIM [60] & 2014 & EGFR & Korea & 80 patients & EGFR up regulation was correlated with chemo resistance. \\
\hline COLQUHOUN [61] & 2006 & EGFR & UK & 110 patients & EGFR expression was correlated with recurrence. \\
\hline Thøgersen [62] & 1999 & EGFR & Denmark & 54 patients & EGFR up regulation was correlated with stage. \\
\hline MANSOUR [63] & 2018 & EGFR & Egypt & 58 patients & EGFR up regulation was correlated with poor prognosis. \\
\hline Bryan [64] & 2015 & EGFR & UK & $\begin{array}{l}436 \text { patients } \\
60 \text { controls }\end{array}$ & EGFR urine levels were correlated with grade and survival. \\
\hline
\end{tabular}


Table 1 All of the tyrosine kinases which have been significantly associated with clinicopathological features of BCa patients in the world (Continued)

\begin{tabular}{|c|c|c|c|c|c|}
\hline Study & Year & Gene & Country & Sample & Results \\
\hline $\mathrm{CHU}[65]$ & 2013 & EGFR & China & $\begin{array}{l}908 \text { patients } \\
1239 \text { controls }\end{array}$ & Polymorphism was correlated with BCa progression. \\
\hline MASON [66] & 2009 & EGFR & USA & $\begin{array}{l}857 \text { patients } \\
1191 \text { controls }\end{array}$ & Polymorphism was correlated with BCa progression. \\
\hline LI [67] & 2015 & $\begin{array}{l}\text { HER2, EGFR, } \\
\text { VEGFR }\end{array}$ & USA & 16 patients & EGFR up regulation \\
\hline $\begin{array}{l}\text { RAJJAYABUN [63, } \\
68]\end{array}$ & 2005 & EGFR, HER2 & UK & 58 patients & HER2 and EGFR up regulations \\
\hline IMAI [69] & 1995 & EGFR, HER2 & Japan & 30 patients & HER2 and EGFR up regulations were correlated with recurrence. \\
\hline LI [70] & 2018 & EGFR, HER2 & China & $\begin{array}{l}56 \text { patients } \\
10 \text { controls }\end{array}$ & HER2 and EGFR expressions were correlated with stage. \\
\hline KASSOUF [71] & 2008 & $\begin{array}{l}\text { EGFR, HER2, } \\
\text { ErbB-3, ErbB-4 }\end{array}$ & Canada & 248 tumors & $\begin{array}{l}\text { EGFR and ErbB-4 expressions were correlated with grade and } \\
\text { survival. }\end{array}$ \\
\hline \multicolumn{6}{|l|}{ RTK class II } \\
\hline $\begin{array}{l}\text { GONZALEZ-ROBIN } \\
{[72]}\end{array}$ & 2014 & IGF1R & USA & 100 patients & IGF1R expression was correlated with pT classification. \\
\hline ROCHESTER [73] & 2007 & IGF1R & UK & $\begin{array}{l}40 \text { tumor tissues } \\
15 \text { control tissues }\end{array}$ & IGF1R expression was correlated with pT classification. \\
\hline Metalli [74] & 2010 & IGF1R & USA & 5 patients & IGF1R up regulation \\
\hline lozzo [75] & 2011 & IGF1R & USA & 40 patients & IGF1R up regulation \\
\hline \multicolumn{6}{|l|}{ RTK class $V$} \\
\hline MARZIONI [76] & 2009 & FGFRI, FGFR2 & Italy & 17 patients & FGFRI, FGFR2, and bFGF up regulations \\
\hline Dueñas [77] & 2015 & PIK3CA, FGFR3 & Spain & 87 patients & $\begin{array}{l}\text { PIK3CA and FGFR3 mutations were correlated with grade and } \\
\text { recurrence. }\end{array}$ \\
\hline JUANPERE [78] & 2012 & $\begin{array}{l}\text { FGFR3, PIK3CA, } \\
\text { KRAS, AKT1, }\end{array}$ & Spain & 88 patients & Mutations were correlated with grade. \\
\hline KOMPIER [79] & 2010 & $\begin{array}{l}\text { FGFR3, HRAS, } \\
\text { KRAS, NRAS, } \\
\text { PIK3CA }\end{array}$ & Netherlands & 257 patients & Mutations were correlated with grade. \\
\hline PANDITH [80] & 2016 & FGFR3 & India & 65 patients & Mutation was correlated with grade and stage. \\
\hline BERTZ [81] & 2014 & FGFR3 & Germany & 61 patients & Mutation was correlated with prognosis and recurrence. \\
\hline BILLEREY [82] & 2013 & FGFR3 & France & 132 patients & FGFR3 mutation was correlated with pT classification. \\
\hline VAN OERS [83] & 2007 & FGFR3 & Germany & 255 patients & FGFR3 mutation was correlated with grade. \\
\hline VAN OERS [84] & 2009 & FGFR3 & UK, France & 280 patients & $\begin{array}{l}\text { FGFR3 mutation was correlated with pT classification and } \\
\text { prognosis. }\end{array}$ \\
\hline $\begin{array}{l}\text { MHAWECH- } \\
\text { FAUCEGLIA [85] }\end{array}$ & 2006 & FGFR3 & USA & 254 patients & FGFR3 up regulation was correlated with grade and stage. \\
\hline BREYER [86] & 2018 & FGFR3 & Germany & 296 patients & FGFR3 expression was correlated with grade. \\
\hline BODOOR [87] & 2010 & FGFR3 & Jordan & 130 patients & FGFR3 expression was correlated with grade and stage. \\
\hline PEDREGOSA [88] & 2017 & FGFR3 & Spain & 55 patients & FGFR3 expression was correlated with tumor size and survival. \\
\hline YANG [89] & 2018 & FGFR3 & China & 52 patients & FGFR3 mutation was associated with better prognosis. \\
\hline $\begin{array}{l}\text { ABDUL-MAKSOUD } \\
{[90]}\end{array}$ & 2016 & FGFR1 & Egypt & $\begin{array}{l}80 \text { patients } \\
80 \text { controls }\end{array}$ & FGFR1 expression was correlated with grade and stage. \\
\hline \multicolumn{6}{|c|}{ RTK classes of VIII, IX, and XIII } \\
\hline MCNEIL [91] & 2014 & c-MET & USA & 183 patients & Urinary MET levels were correlated with muscle invasion. \\
\hline $\mathrm{KIM}[92]$ & 2015 & $\begin{array}{l}\text { c-MET, AXL, } \\
\text { PDGFR }\end{array}$ & Korea & $\begin{array}{l}165 \text { patients } \\
34 \text { controls }\end{array}$ & Expressions were correlated with prognosis. \\
\hline CHENG [93] & 2005 & c-MET & Taiwan & 183 patients & RON and MET expressions were correlated with survival. \\
\hline Abraham [94] & 2006 & EphA2 & USA & 64 tumor tissues & EphA2 expression was correlated with tumor stage. \\
\hline
\end{tabular}


Table 1 All of the tyrosine kinases which have been significantly associated with clinicopathological features of BCa patients in the world (Continued)

\begin{tabular}{|c|c|c|c|c|c|}
\hline Study & Year & Gene & Country & Sample & Results \\
\hline & & & & 13 normal tissues & \\
\hline $\mathrm{XIA}[95]$ & 2006 & EphB4 & USA & 15 patients & EphB4 up regulation \\
\hline Xie [96] & 2017 & DDR1 & China & 44 patients & DDR1 expression was correlated with poor prognosis. \\
\hline Tsai [97] & 2016 & DDR2 & Taiwan & 340 patients & $\begin{array}{l}\text { DDR2 up regulation was correlated with poor prognosis, infiltrative } \\
\text { pattern, higher grade, advanced T stage, and metastatic status. }\end{array}$ \\
\hline \multicolumn{6}{|c|}{ Other tyrosine kinase receptors } \\
\hline LAl [98] & 2010 & BDNF, TrkB & Taiwan & 116 tumor tissues & BDNF and TrkB up regulations \\
\hline PAN [99] & 2005 & c-KIT & USA & 52 patients & c-KIT up regulation \\
\hline SHAMS [100] & 2013 & c-KIT & Egypt & 120 patients & c-KIT up regulation \\
\hline \multicolumn{6}{|c|}{ Non-receptor tyrosine kinases } \\
\hline ASAI [101] & 2018 & FES & Japan & 203 patients & FES up regulation was correlated with poor prognosis. \\
\hline NOMURA [102] & 2015 & DYRK2 & Japan & 44 patients & DYRK2 expression was correlated with survival. \\
\hline GUO [103] & 2011 & ETK & USA & 233 patients & ETK up regulation was correlated with grade and prognosis. \\
\hline
\end{tabular}

cellular localization [120]. HER2/neu triggers PI3K/AKT and Ras/Raf/MAPK signaling pathways as the stimulators of FASN. It has been observed that there were significant correlations between FASN expression, tumor size, grade, recurrence, and stage. Moreover, there was a correlation between FASN and HER2/neu which had prognostic value among NMIBC patients. HER2/neu up regulated the FASN through PI3K and MAPK pathways. FASN and HER2/neu up regulations were associated with shorter RFS and poor PFS among NMIBC cases [42]. HER2 up regulation has been observed in a sample of NMIBC patients which was significantly correlated with advanced grade and stage, bigger size, and adjacent tissues invasion. HER2 positive patients had markedly lower progression-free survival in comparison with HER2 negative cases [43]. It has been reported that the over expression of ERBB2 was significantly correlated with high grade and advanced stage tumor among a group of NMIBC patients [44]. A significantly higher level of urinary HER2/neu was also observed among a sample of NMIBC patients compared with normal subjects. Moreover, HER2/neu level/urinary creatinine ratio was significantly associated with advanced tumor grade [45]. It has been reported that the patients with positive HER2 expression had significantly shorter disease-free survival compared with negative HER2 expression cases in a sample of MIBC patients. This difference was more significant in patients with advanced stage and grade who were candidates for adjuvant treatment. The HER2/ neu expression was significantly associated with higher tumor grade and stage, and lymph nodes involvement. Moreover, patients with HER2 up regulation had a worse disease-specific survival compared with normal HER2 expressed patients [46]. It has been observed that the HER2 and NFkB up regulations had a key role in tumor cells resistance against chemotherapy among a sample of MIBC patients. HER2 and NFkB Over expressions were significantly correlated with poorer survival in chemotherapeutic-treated MIBC patients who were undergone cystectomy. High expression levels of NFkB were also significantly associated with drug resistance in MIBC patients. Therefore, HER2 and NFkB up regulations can be resulted in a worse prognosis in chemotherapeutic-treated MIBC patients who were undergone cystectomy [47]. Another study has been shown that there was a significant association between HER2 up regulation and CRT resistance. Targeting HER2 improves prognosis of MIBC cases that were treated with CRT-based bladder-sparing methods [48].

Upper urinary tract urothelial carcinoma (UUTUC) is an uncommon type with frequency of $5-10 \%$ among all urothelial carcinomas. It has been shown that there was significant association between HER2 protein up regulation, gene amplification, grade, and shorter recurrence period. HER2 positivity was more in patients over 70 years old compared with patients under 70 years old [49]. Plasmacytoid urothelial carcinoma is also another rare type of urothelial carcinoma that is distinguished by plasma-cell-like cancer cells [121, 122]. It has been reported that the plasmacytoid urothelial carcinoma patients had HER2 protein up regulation and gene amplification [50]. Heregulin (HRG) is ligand of ERBB family of receptors that can regulate cell proliferation, apoptosis, and differentiation [123-125]. It has been reported that the HER3 and HER4 up regulations and their initiating ligands are correlated with good prognosis among $\mathrm{BCa}$ patients. Patients with high HER3 and HER4 expressions had increased survival rate. There was significant HRG2b loss in invasive tumors in comparison with non-invasive tumors. Moreover, there was a 
significant association between (HER3 and HER4) and (HRG2 and HRG4) expressions [51]. It has been show that there were significant different levels of ErbB4 protein expressions between a sample of bladder tumors and normal margins. EGFR and HER2 were down regulated and up regulated respectively in tumor tissues in comparison with non-malignant bladder tissues [52].

EGFR functions in a dimeric structure of different EGF receptors for the signal transduction [126, 127]. Dimeric pairs are related to the concentration of both receptors and specific ligands and also the affinities between receptors $[128,129]$. It has been reported that there were associations between the elevated levels of growth factors and also their receptors and tumor recurrence in a sample of BCa patients. Tumor tissues had increased levels of EGFR and related growth factors at early stages [53]. Another study has been reported that there was EGFR up regulation in invasive $\mathrm{BCa}$ tumors. Progression free survival rate in patients without any progression were significantly lower among EGFR positive cases [54]. It has been reported that there were associations between EGFR expression, tumor grade, and stage $[55,56]$. The increased EGFR levels of expressions were significantly associated with advanced stage and overall survival rates among muscle invasive bilharzial bladder cancer (MI-BBC) patients [57]. Another study has been shown that the EGFR up regulation was significantly correlated with aneuploidy and polysomy in a sample of BCa tumors. A significant association was also observed between high expression of EGFR and P53. Moreover, up regulation was positively associated with tumor invasiveness, aneuploidy, non-papillary type, and grade. Therefore, highly expressed EGFR is typically a delayed event during $\mathrm{BCa}$ progression due to genomic instability [58]. EGF and five other ligands capable of binding to EGFR are among the various family-specific EGF ligands, while heregulins are the HER3 and HER4 ligands [130]. The expression levels of HER1-4 were assessed in bladder tumors, which showed that the up regulation of HER3 and/or HER4 was a protective factor against the negative outcome of HER1 and/or HER2 over expression. Over expression of either HER1 or HER2 in HER3 and HER4 down regulated tumors were correlated with decreased survival. Therefore, HER1 and HER2 over expressions resulted in poor prognosis and tumor progression only if there were HER3 and HER4 under expressions. Patients with high expression levels of HER1 but HER3 and HER4 down regulations had a poorer prognosis than those with high levels of HER1, HER3, and HER4. Furthermore, patients expressing high levels of HER2 but HER3 and HER4 down regulations had a significantly lower survival rate compared with patients with up regulated HER2, HER3, and HER4 [59].
Radical cystectomy is the standard treatment option for MIBC, however about half of these cases had tumor metastasis during 2 years [131, 132]. Patients with metastatic $\mathrm{BCa}$ receive systemic Cisplatin-based therapy as the first-line treatment modality, which has a poor prognosis in advanced tumor stage [133, 134]. It has been reported that the EGFR up regulation was correlated with chemo resistance in a sample of $\mathrm{BCa}$ patients. The S100A9 and EGFR suppressions decreased tumor cells viability and Cisplatin-resistance. Moreover, the S100A9 and EGFR up regulations were observed in MIBC patients [60]. Another study has been reported that there was a significant correlation between EGFR negative tumor and positive radio therapeutic response at 3month check cystoscopy. Lack of radiotherapy response at 3-month check cystoscopy was an autonomous prognostic indicator for the reduced survival rate of bladder malignancy. Positive EGFR status predicted future local relapse following a previous complete radio therapeutic response [61]. It has been shown that there was EGFR up regulation in muscle invasive in comparison with lower invasive bladder tumors which were also correlated with advanced tumor stage. EGFR and TGF- $\alpha$ co-expression was significantly correlated with muscle invasion [62]. The EGFR up regulation can predict a poor prognosis compared with lack of EGFR expression in a sub population of MIBC patients. There was also a significant association between EGFR over expression and tumor relapse after adjuvant chemotherapy for advanced $\mathrm{BCa}$, which introduced EGFR as a useful prognostic marker of $\mathrm{BCa}$ [63]. It has been shown that some high-grade bladder tumor patients had increased urinary level of EGFR. EGFR levels in urine can be used as a predictor of survival [64]. The EGFR 3'UTR 774 T >C polymorphism can be associated with higher risk of $\mathrm{BCa}$ progression. Patients with EGFR 774CC genotype were significantly more susceptible to $\mathrm{BCa}$ in comparison with 774TT/TC genotype [65]. There was also a significant correlation regarding EGFR_03 and EGFR_05 variants with a higher risk of BCa progression, and EGFR_05 and EGFR_1808 variants with a prolonged survival. EGFR_03 and EGFR_05 polymorphisms were correlated with higher BCa risk. Patients with polymorphic EGFR alleles showed higher survival rate than patients with wild-type EGFR. However, mutated type of the EGF_04 ligand showed lower survival rate than wild-type [66].

Micropapillary urothelial carcinoma (MPUC) is an aggressive urothelial cancer with poor prognosis which is due to the high tendency of tumor for lymphovascular invasion. Majority of the MPUC patients have a high grade and stage tumor at the time of diagnosis [135]. It has been shown that there was a significant EGFR up regulation in a sample of MPUC patients [67]. Tumors with muscle invasion (stage T2-T4) showed a significant 
higher progression and metastasis, with decreased 5-year survival rates. Cell-to-cell and cell-to-matrix signals are mainly transmitted through tyrosine-kinases that results in alteration of cell differentiation, motility, attachment, and apoptosis [17]. It has been reported that there were HER2 and EGFR up regulations in a sample of $\mathrm{BCa}$ in comparison with typical urothelium. The HER2 and EGFR over expressions had an important role in the early stages of tumor progression. Moreover, there were significant correlations between HER2 expression and HER2 and EGFR coexpression in patients with T1 disease [68]. It has been reported that there was a significant association between nuclear positivity of c-MYC and HER2 up regulation among a group of transitional cell $\mathrm{BCa}$ patients. Cytoplasmic c-MYC expression was also correlated with grade, papillary status, and EGFR/ HER2 up regulation [136]. EGFR- and/or HER2 up regulation has been also reported to have a significant association with higher frequency of recurrence in $\mathrm{BCa}$ patients [69]. It has been observed that there was a significant positive association between HER2 and EGFR expressions in a sub population of transitional $\mathrm{BCa}$ patients. Bladder tumor cells had significantly higher levels of EGFR and HER2 expressions compared with controls. Patients with advanced tumor grade and stage, and tumor relapse had significant increased expression of EGFR in comparison with patients with lower grade and stage of tumor, and lack of recurrence. Patients with advance stages and tumor relapse also showed increased levels of HER2 expression compared with recurrence free patients with lower tumor stages [70]. It has been shown that the EGFR up regulation and ErbB4 down regulation were significantly correlated with tumor aggressiveness, advance grade, and poor overall survival in a sub population of $\mathrm{BCa}$ patients. The patients with EGFR down regulation had higher recurrence-free survival in comparison with patients with EGFR up regulation. Patients without ErbB4 down regulation had better 5 -year overall survival and were more likely to have small, low-grade, and non-invasive tumors [71].

\section{RTK class II}

Insulin-like growth factor-1 receptor (IGF1R) is belonged to the class II RTKs which have pivotal functions in regulation of cell proliferation, migration, apoptosis, and differentiation. IGF-IR has an anti-apoptotic function during tumor progression [137]. It has been shown that the IGF1R expression was correlated with the race and $\mathrm{pT}$ classification in malignant UC cases. There was a negative association between $\mathrm{pT}$ classification and IGF1R expression in which the IGF1R over expression was less in $\mathrm{pT} 4$ cases compared with lower $\mathrm{pT}$ categories. IGF1R over expression was significantly correlated with mortality which can be introduced as a prognostic factor of $\mathrm{BCa}$ [72]. Another study has been reported that there was significant IGF1R over expression in a sample of $\mathrm{BCa}$ tissues compared with healthy urothelium. Both invasive and superficial (Ta-T1) bladder tumors had higher expression levels of IGF1R compared with normal bladder tissue [73]. It has been observed that the IGF-IR promotes bladder tumor cells migration and invasion through AKT-ERK related activation of Paxillin. Since, phosphorylated Paxillin colocalizes with FAK in focal adhesion in migrating cells, Paxillin suppression reduced the invasion of 5637 and T24 cell lines. There was also IGF-IR up regulation in a sample of invasive $\mathrm{BCa}$ tissues compared with normal margins [74]. Decorin is belonged to the small leucinerich proteoglycans involved in tumor progression via RTKs suppression [75, 138]. It has been shown that there were significant IGF-IR over expression in high grade in comparison with low grade $\mathrm{BCa}$ samples. There was also an inverse correlation between the levels of decorin and IGF-IR expressions in BCa. Moreover, Decorin suppressed tumor cell invasion through IGF-IR inhibition [139].

\section{RTK class $V$}

Basic Fibroblast Growth Factor (bFGF) is a cationic protein that binds with heparin and is involved in angiogenesis and tumor progression. The basic FGFR is belonged to the class V of RTKs, and syndecans are essential for its activation. Ligand binding causes FGFR dimerization, which leads to the kinase domain autophosphorylation and phosphorylation of effector signaling proteins. Syndecans binding with both bFGF and their FGFRs functions as stimulators while syndecans that bind only bFGF operate as signaling inhibitors. It has been shown that there were significant FGFRI, FGFR2, bFGF, and syndecan1-4 up regulations in a sample of $\mathrm{BCa}$ tissues [76]. Different changes and variations have been detected in the members of phosphatidylinositol 3-kinase (PI3K) pathway in urinary $\mathrm{BCa}[140,141]$. This pathway has key roles in regulation of cellular growth and survival [142]. It has been reported that the PIK3CA mutations and amplification were a preliminary and prevalent occurrence among NMIBC patients which were correlated with reduced tumor relapse. In low-grade tumors there was also a correlation between PIK3CA and FGFR3 mutations. Moreover, patients with wt PIK3CA and FGFR3 mutated tumors had significantly higher recurrence rates. An exceptionally high rate of PIK3CA mutations and gene amplifications were particularly found in T1 and T2 tumors. Mutations and amplifications in PIK3CA induced AKT function [77]. PI3K can be activated by FGFR or ERBB through the binding of RAS to PIK3CA. It has been shown that the majority of UCC cases had mutations in PIK3CA, FGFR3, HRAS, 
KRAS, BRAF, and AKT1 genes. Mutations were significantly more frequent in FGFR3, PIK3CA, and FGFR3. The frequencies of mutations were negatively associated with grade. FGFR3mut and FGFR3mut- PIK3CAmut genotypes were correlated with low grade tumors, while the KRASmut- PIK3CAmut- and AKT1mut were observed in high-grade tumors [78]. Another study has been shown that the majority of patients with low-grade NMI-BC had a mutation in KRAS, NRAS, HRAS, PIK3CA, and FGFR3 genes. Therefore, mutational analysis of these genes along with regular cystoscopic examinations can be an efficient method of following-up among patients with grade 1-2 NMI-BC [79]. It has been observed that there was significant correlations between mutated FGFR3 and lower tumor stage/grade [80]. BCa patients with mutated FGFR3 had higher rate of vascularization in comparison with wild-type FGFR3. FVIII up regulation was the only angiogenic factor associated with mutated FGFR3. The T1 MIBC patients with mutated FGFR3 had significantly higher risk of recurrence compared with wild-type FGFR3 carriers. FGFR3 was also a poor prognostic factor and promoted tumor angiogenesis. Therefore, FGFR3-targeted therapies can be effective in reducing tumor angiogenesis [81]. Most of bladder tumors $(75-80 \%)$ are papillary noninvasive (pTa) or superficially invasive (pT1) urothelial tumors, whereas the others (20-25\%) are muscle-invasive (pT2). FGFR3 mutations are more common in pTa bladder tumors [82, 143, 144], less regular in pT1G3 tumors $[145,146]$, and rare in carcinoma in situ (pTis) $[82,146]$. The BCa patients with a FGFR3 mutation appeared to have a better outcome compared with mutation free patients [144]. It has been reported that the FGFR3 and CK20 were efficient prognostic factors of pTa bladder tumors, since it can distinguish the differentiated tumors with FGFR3 mutations. The FGFR3 mutation with a normal CK20 expression pattern was observed in lowgrade non-invasive papillary tumors [83]. It has been observed that the FGFR3 mutations were significantly more common in pTa $\mathrm{BCa}$ tumors. The patients with mutant FGFR3 had significantly lower death rate. The FGFR3 mutations can precisely determine patients with invasive tumor who were at lower risk of progression. The carriers of FGFR3 mutations had better prognosis [84]. Another study has been shown that the prevalence of FGFR3 mutation was significantly higher in pTa tumors compared with carcinoma in situ (CIS), pT1, and pT2-4 among a sub population of $\mathrm{BCa}$ patients. There were also significant correlations between FGFR3 mutations and low grade tumors [82]. It has been reported that the FGFR3 up regulation was more common in welldifferentiated in comparison with poorly-differentiated tumors and in low stage tumors in comparison with advance stage tumors among $\mathrm{BCa}$ patients. There were significant associations between loss of FGFR3, stage, and grade [85]. A negative association was also reported between the levels of FGFR3 expression and grade. There was also significant inverse correlation between CDKN2A/p16 and FGFR3 expressions. CDKN2A/p16 up regulation and FGFR3 down regulation were significantly associated with poor progression-free survival [86]. MAP kinase, STAT1, PI3K-AKT, and PLCY are important signaling pathways to mediate the FGFR3 functions [147-149]. It has been shown that there was a declining trend of FGFR3 expression from pTa toward pT3 cases in a sample of BCa cases. FGFR3 was also positive in 45,26 , and $30 \%$ of G1, G2 and G3 cases, respectively. Moreover, there was association between mutation and FGFR3 over expression which were frequent in primary stage (pTa and pT1) and low grade (G1 and G2) BCa tumors [87]. It has been shown that there was FGFR3 up regulation in a sample of $\mathrm{BCa}$ tumor tissues compared with normal mucosa. Tumor size was also correlated with FGFR3 expression. Moreover, the up regulations of FGFR3, PI3Kp110, PI3KClassIII, and AKT were also correlated with recurrence free survival among T1 BCa patients [88]. ERCC1 over expression and FGFR3 mutation were associated with a better response to the non-adjuvant chemotherapy in a group of MIBC patients [89]. It has been shown that the mRNA levels of FGFR1 and CK20 were significantly higher in BCa tissues in comparison with normal margins. The invasive tumors had significantly higher levels of FGFR1 and CK20 expressions compared with non-invasive tumors. FGFR1 or CK20 were sensitive markers to separate the invasive and non-invasive tumors. The levels of FGFR1 and CK20 expressions were significantly higher in invasive tumors (pT2-pT4) compared with non-invasive tumors (pTis, pTa, and pT1). The expression levels of FGFR1 and CK20 were also correlated with stage and grade [90].

\section{RTK classes of VIII, IX, and XIII}

Tumor is limited to the mucosal layer in almost $70 \%$ of the new $\mathrm{BCa}$ cases. The rest of patients have an advanced tumor stages with local lymph node involvement, muscles invasion, and distant metastases at the time of diagnosis. About $50 \%$ of the MIBC patients does not respond to chemotherapy, radiotherapy, or surgical resection which results in a survival time lower than 5 years $[116,150]$. The gold standard treatment option for $\mathrm{BCa}$ patients with distant metastases is the Platinum-based chemotherapy which has a $15 \%$ of 5 -year survival rate and a median survival of 15 months [151]. MET is a cell surface RTK mainly produced in epithelial cells. MET signaling is critical for normal cellular development and homeostasis; however, it has also been shown to be involved in invasive tumors and distant metastasis [152]. It 
has been reported that the urinary MET levels could be an efficient marker of differentiating between $\mathrm{BCa}$ patients and healthy subjects, and also differentiating between MIBC and NMIBC patients [91]. Although, pharmaceutical inhibition of the RTK pathway function using Gefitinib had modest outcomes, it remains the gold standard treatment for $\mathrm{BCa}$ patients [153, 154]. The activation of c-MET by hepatocyte growth factor (HGF) worsen the malignant features of tumor cells which results in a higher rate of cells motility, proliferation, metastasis, and invasion [155]. Activation of c-MET induces other signaling proteins such as GRB2, GAB1, SHC, PLC1, and PI3-K [156]. Microarray analysis on RTK indicated that the PDGFR and AXL have interaction with c-MET [157]. It has been reported that the lack of c-MET expression renders less aggressiveness and more Cisplatin response in $\mathrm{BCa}$. In contrast, c-MET up regulation had a significant association with worse clinical outcome and shorter overall survival among MIBC patients. The PDGFRL up regulation was also significantly correlated with a poorer prognosis. Moreover, NMIBC patients had an increased levels of AXL and PDGFR expressions compared with MIBC patients [92]. Recepteur d'Origine Nantais ( $\mathrm{RON}$ ) is a particular receptor tyrosine-kinase in the MET family [158]. It has been shown that there were correlations between RON or MET expressions and tumor aggressiveness and reduced survival. RON up regulation promoted the cell proliferation and migration. RON expression was also directly correlated with grade, size, and tumor stage among $\mathrm{BCa}$ patients. Moreover, RON/MET expression was correlated with reduced overall survival [93]. The Eph receptor is belonged to the RTK family that is regulated by ephrin ligands. Eph-ephrin interaction is associated with cell migration and neoplastic transformation [159]. It has been reported that there was a significant EphA2 up regulation in a sample of urothelial tumors compared with normal tissues. The levels of EphA2 expression was also significantly correlated with tumor stage. Moreover, there was a converse correlation between E-cadherin and EphA2 expressions in advanced tumor stages [94]. EphB4 is a member of the Eph receptors which has key functions in angiogenesis, neural development, and pattern formation [160-163]. EphB4 and its specific ligand, EphrinB2, are both transmembrane proteins that are typically expressed on venous and arterial endothelium, respectively. Deregulation of EphB4 has been demonstrated in various tumors of breast, prostate, and lung [164-167]. Activation of EphB4 regulates cell attachment and migration [168-171]. Frequent EphB4 up regulation was reported among a sample of $\mathrm{BCa}$ patients. While, majority of tumor tissues showed a high expression of EphB4, normal urothelial cells displayed very little or lack of EphB4 expression. P53 is a regulator of
EphB4 via MAPK and PI3K signaling pathways. EphB4 was up regulated by PI3K/AKT pathway. The EphB4 suppression also reduced tumor cells invasion which can be due to MMP9 down regulation. Moreover, they observed BCL-XL down regulation following the EphB4 knockdown in $\mathrm{BCa}$ cells. Therefore, EphB4 suppression reduced tumor progression and increased apoptosis [95]. Discoidin domain receptors (DDRs) are a class of RTKs which are activated by collagens. DDR1 can be activated by most collagen types, whereas DDR2 can be activated only by type I and III collagens [172]. The collagenDDR1 binding increases the self-renewal and migration of non-cancerous cells [173, 174]. A high level of DDR1 in solid malignant tumors was associated with poor prognosis [175]. It has been reported that there was a significant increased levels of DDR1 expression in $\mathrm{BCa}$ tissues which was associated with poor prognosis. DDR1 activation also increased tumor invasion through ZEB1 and SLUG up regulations in bladder tumor cells [96]. DDR2 promotes the EMT through the ECM blockade. The activated DDR2 becomes docking sites for adaptor proteins, resulting in the MMP2 up-regulation [176]. It has been observed that there was a significant DDR2 up regulation in a sample of urothelial carcinoma patients which was associated with poor prognosis, infiltrative pattern, higher grade, advanced $\mathrm{T}$ stage, and metastatic status [97].

\section{Other tyrosine-kinase receptors}

Brain-derived neurotrophic factor (BDNF) is a member of the neurotrophin family of growth factors associated with neural differentiation and survival through binding to the Tropomyosin receptor kinase B (TrKB) [177]. BDNF/TrKB pathway has been reported to be involved in different solid cancers such as lung, prostate, and pancreatic ducts [178180]. It has been observed that there were increased levels of BDNF and TrKB expressions among a sub population of transitional cell carcinomas (TCC) patients compared with healthy subjects. However, differences were significant in grade 3 TCC for BDNF expression, and in grade 1 and 3 TCC for TrKB expression. Therefore, $\operatorname{TrKB}$ and/or BDNF up regulation can be introduced as efficient markers of early detection among $\mathrm{BCa}$ patients [98]. C-KIT is a tyrosine-kinase receptor involving in carcinogenesis and hematopoiesis $[181,182]$. The c-KIT up regulation has been reported in various cancers such as gastrointestinal, lung, and breast cancers [183-185]. Since, c-KIT up regulation has been observed in a marked population of a sample of small cell $\mathrm{BCa}$ patients, c-KIT targeted therapies can be an effective therapeutic method among these patients [99]. The c-KIT has key developmental functions and mainly 
expressed in melanocytes, interstitial cells of Cajal, erythroid and mast cell lineages [186-188]. The prevalence of c-KIT mutation and its expression levels were assessed in a sub population of bladder SCC patients which showed c-KIT up regulation in majority of cases. Bilharzial ova positive patients also showed a significantly higher expression levels of c-KIT compared with Bilharzial ova negative cases [100].

\section{Non-receptor tyrosine-kinases}

Feline Sarcoma (FES) and FES-related protein (FER) are a separate sub-family of non-receptor tyrosinekinases [189]. Down regulation of FES represses the progression of renal cell carcinoma cells [190]. It was also shown that the increased FES expression was associated with a more aggressive tumor and shorter recurrence-free survival following surgical resection [191]. The FES was significantly down regulated in tumor cells compared with normal urothelial cells. A positive association was also observed between FES expression level and tumor cells invasion in patients with high-grade tumors. Moreover, FES up regulation was determined as a negative prognostic predictor of metastasis after radical surgery in patients with highgrade malignancies [101]. Dual-specificity tyrosine phosphorylation-regulated kinases (DYRKs) constitute a subfamily of protein kinases which have the ability to phosphorylate aromatic (tyrosine) besides aliphatic (serine and threonine) residues [192-194]. DYRKs are involved in regulation of cellular proliferation, differentiation, and survival $[195,196]$. DYRK2 stimulates cell apoptosis following DNA damages by p53 phosphorylation during genotoxic stress [197]. It has been reported that there was a significant correlation between DYRK2 over expression and higher diseasespecific survival among chemotherapeutic-treated T1 high-grade and $\mathrm{T} 2 \mathrm{BCa}$ patients. Therefore, assessing the levels of DYRK2 could be a predictive factor to detect patients with $\mathrm{T} 1$ high-grade and $\mathrm{T} 2 \mathrm{BCa}$ that will probably show a good response to neoadjuvant chemotherapeutic treatment [102]. Epithelial and endothelial tyrosine-kinase (ETK) is a family of nonreceptor tyrosine-kinases which can be activated by cytokines, hormones, growth factors, and ECM [198]. ETK is involved in regulation of cell proliferation, differentiation, motility, and survival. It has been reported that the ETK levels rises gradually during the $\mathrm{BCa}$ progression. There were also significant correlations between ETK up regulation, higher tumor grade, and poor prognosis. Suppression of ETK in bladder tumors reduced activity of AKT and STAT3. Therefore, the ETK over expression can be the reason of increased AKT and STAT3 activity in bladder tumors [103].

\section{Conclusions}

It was observed that the class I and V of RTKs were the most reported tyrosine-kinases among $\mathrm{BCa}$ patients in the world. This review highlights the importance of tyrosine-kinases as critical markers in early detection and therapeutic purposes among $\mathrm{BCa}$ patients and clarifies the molecular biology of tyrosine-kinases during $\mathrm{BCa}$ progression and metastasis.

\section{Abbreviations \\ BCa: Bladder cancer; US: United States; NMIBC: Non-muscle-invasive bladder cancer; MIBC: Muscle-invasive bladder cancer; TKs: Tyrosine-kinases; \\ EGFR: Epidermal growth factor receptor; PDGFR: Platelet-derived growth factor receptor; VEGFR: Vascular endothelial growth factor receptor; FGFR: Fibroblast growth factor receptor; HGFR: Hepatocyte growth factor receptor; TKIs: Tyrosine-kinase inhibitors; RTKs: Receptors of tyrosine-kinases; FASN: Fat synthase; UUTUC: Upper urinary tract urothelial carcinoma; HRG: Heregulin; MPUC: Micropapillary urothelial carcinoma; IGF1R: Insulin-like growth factor-1 receptor; bFGF: Basic Fibroblast Growth Factor; \\ CIS: Carcinoma in situ; HGF: Hepatocyte growth factor; RON: Recepteur d'Origine Nantais; BDNF: Brain-derived neurotrophic factor; TCC: Transitional cell carcinomas; FES: Feline Sarcoma; FER: FES-related protein; ETK: Epithelial and endothelial tyrosine-kinase; PI3K: Phosphatidylinositol 3-kinase; \\ DDRs: Discoidin domain receptors}

\section{Acknowledgements}

Not applicable

\section{Authors' contributions}

$A S Z, A H B, H R R$, and MMojarrad were involved in search strategy and drafting. MMoghbeli supervised the project and revised and edited the manuscript. All authors read and approved the final manuscript.

\section{Funding}

Not applicable.

\section{Availability of data and materials}

The datasets used and/or analyzed during the current study are available from the corresponding author on reasonable request.

Ethics approval and consent to participate

Not applicable.

Consent for publication

Not applicable.

\section{Competing interests}

The authors declare that they have no competing interests.

\section{Author details}

'Student Research Committee, Faculty of Medicine, Mashhad University of Medical Sciences, Mashhad, Iran. ${ }^{2}$ Department of Medical Genetics and Molecular Medicine, School of Medicine, Mashhad University of Medical Sciences, Mashhad, Iran.

Received: 27 April 2020 Accepted: 2 July 2020

Published online: 14 August 2020

\section{References}

1. Bray F, et al. Global cancer statistics 2018: GLOBOCAN estimates of incidence and mortality worldwide for 36 cancers in 185 countries. CA Cancer J Clin. 2018;68(6):394-424.

2. Siegel RL, Miller KD, Jemal A. Cancer statistics, 2020. CA Cancer J Clin. 2020; 70(1):7-30.

3. Antoni $\mathrm{S}$, et al. Bladder cancer incidence and mortality: a global overview and recent trends. Eur Urol. 2017;71(1):96-108.

4. Taylor JA, Kuchel GA. Bladder cancer in the elderly: clinical outcomes, basic mechanisms, and future research direction. Nat Clin Pract Urol. 2009:6(3): $135-44$. 
5. Lombard AP, Mudryj M. The emerging role of the androgen receptor in bladder cancer. Endocr Relat Cancer. 2015;22(5):R265-77.

6. Volanis $D$, et al. Environmental factors and genetic susceptibility promote urinary bladder cancer. Toxicol Lett. 2010;193(2):131-7.

7. Mojarrad M, Moghbeli M. Genetic and molecular biology of bladder cancer among Iranian patients. Mol Genet Genomic Med. 2020;1:e1233.

8. Kaufman DS, Shipley WU, Feldman AS. Bladder cancer. Lancet. 2009; 374(9685):239-49.

9. Sanli O, et al. Bladder cancer. Lancet. 2017;3(1):1-19.

10. Martinez Rodriguez RH, Buisan Rueda O, Ibarz L. Bladder cancer: present and future. Med Clin (Barc). 2017;149(10):449-55.

11. Vasekar M, Degraff D, Joshi M. Immunotherapy in bladder cancer. Curr Mol Pharmacol. 2016;9(3):242-51.

12. Martin-Doyle W, Kwiatkowski DJ. Molecular biology of bladder cancer. Hematol Oncol Clin North Am. 2015;29(2):191-203.

13. Manning $G$, et al. The protein kinase complement of the human genome. Science. 2002;298(5600):1912-34.

14. Hubbard MJ, Cohen P. On target with a new mechanism for the regulation of protein phosphorylation. Trends Biochem Sci. 1993;18(5):172-7.

15. Nattel $S$, et al. Arrhythmogenic ion-channel remodeling in the heart: heart failure, myocardial infarction, and atrial fibrillation. Physiol Rev. 2007;87(2): $425-56$

16. Hanks SK, Hunter T. Protein kinases 6. The eukaryotic protein kinase superfamily: kinase (catalytic) domain structure and classification. FASEB J. 1995;9(8):576-96.

17. Robinson DR, Wu Y-M, Lin S-F. The protein tyrosine kinase family of the human genome. Oncogene. 2000;19(49):5548-57.

18. Pusztai L, et al. Growth factors: regulation of normal and neoplastic growth. J Pathol. 1993;169(2):191-201.

19. Moghbeli $\mathrm{M}$, et al. Association of PYGO2 and EGFR in esophageal squamous cell carcinoma. Med Oncol. 2013;30(2):516.

20. Moghbeli $\mathrm{M}$, et al. ErbB1 and ErbB3 co-over expression as a prognostic factor in gastric cancer. Biol Res. 2019;52(1):2.

21. Krause DS, Van Etten RA. Tyrosine kinases as targets for cancer therapy. N Engl J Med. 2005;353(2):172-87.

22. Lahiry $\mathrm{P}$, et al. Kinase mutations in human disease: interpreting genotypephenotype relationships. Nat Rev Genet. 2010;11(1):60-74.

23. Karpov OA, et al. Receptor tyrosine kinase structure and function in health and disease; 2015.

24. Mitra AP, Cote RJ. Molecular pathogenesis and diagnostics of bladder cancer. Annu Rev Pathol. 2009:4:251-85.

25. McDonell LM, et al. Receptor tyrosine kinase mutations in developmental syndromes and cancer: two sides of the same coin. Hum Mol Genet. 2015 24(R1):R60-6.

26. Hänze J, et al. Effects of multi and selective targeted tyrosine kinase inhibitors on function and signaling of different bladder cancer cells. Biomed Pharmacother. 2018;106:316-25.

27. Kim SH, et al. Bgj398, a pan-fgfr inhibitor, overcomes paclitaxel resistance in urothelial carcinoma with fgfr1 overexpression. Int J Mol Sci. 2018;19(10):3164

28. Agarwal PK, et al. Emerging drugs for targeted therapy of bladder cancer. Expert Opin Emerg Drugs. 2007;12(3):435-48.

29. Alonso-Gordoa T, et al. Targeting tyrosine kinases in renal cell carcinoma: "new bullets against old guys". Int J Mol Sci. 2019;20(8):1901.

30. Li Q, et al. MicroRNAs: key players in bladder cancer. Mol Diagn Ther. 2019; 23(5):579-601.

31. Soria F, et al. Molecular markers in bladder cancer. World J Urol. 2019;37(1): $31-40$.

32. Coombs L, et al. Immunocytochemical localization of c-erbB-2 protein in transitional cell carcinoma of the urinary bladder. J Pathol. 1993;169(1):35-42.

33. Simon R, et al. HER-2 and TOP2A coamplification in urinary bladder cancer. Int J Cancer. 2003;107(5):764-72.

34. Nadoushan MRJ, et al. Overexpression of HER-2/neu oncogene and transitional cell carcinoma of bladder. Urol J. 2009:4(3):151-4.

35. Krüger $\mathrm{S}$, et al. HER2 overexpression in muscle-invasive urothelial carcinoma of the bladder: prognostic implications. Int J Cancer. 2002;102(5):514-8.

36. Coogan $\mathrm{CL}$, et al. HER-2/neu protein overexpression and gene amplification in human transitional cell carcinoma of the bladder. Urology. 2004;63(4): 786-90.

37. Latif $Z$, et al. HER2/neu gene amplification and protein overexpression in G3 PT2 transitional cell carcinoma of the bladder: a role for anti-HER2 therapy? Eur J Cancer. 2004;40(1):56-63.
38. Latif $Z$, et al. HER2/neu overexpression in the development of muscleinvasive transitional cell carcinoma of the bladder. Br J Cancer. 2003;89(7): 1305-9.

39. Fleischmann A, et al. Her2 amplification is significantly more frequent in lymph node metastases from urothelial bladder cancer than in the primary tumours. Eur Urol. 2011;60(2):350-7.

40. Hansel DE, et al. HER2 overexpression and amplification in urothelial carcinoma of the bladder is associated with MYC coamplification in a subset of cases. Am J Clin Pathol. 2008;130(2):74-281.

41. Eissa S, et al. HER2/neu expression in bladder cancer: relationship to cell cycle kinetics. Clin Biochem. 2005;38(2):142-8.

42. Abdelrahman AE, et al. Fatty acid synthase, Her2/neu, and E2F1 as prognostic markers of progression in non-muscle invasive bladder cancer. Ann Diagn Pathol. 2019;39:42-52.

43. Ding $\mathbf{W}$, et al. Human epidermal growth factor receptor 2: a significant indicator for predicting progression in non-muscle-invasive bladder cancer especially in high-risk groups. World J Urol. 2015;33(12):1951-7.

44. Breyer J, et al. ESR1, ERBB2, and Ki67 mRNA expression predicts stage and grade of non-muscle-invasive bladder carcinoma (NMIBC). Virchows Arch. 2016;469(5):547-52.

45. Arikan $\mathrm{O}$, et al. Clinical significance of serum and urinary HER2/neu protein levels in primary non-muscle invasive bladder cancer. Int Braz J Urol. 2015; 41(6):1080-7.

46. Kolla SB, et al. Prognostic significance of Her2/neu overexpression in patients with muscle invasive urinary bladder cancer treated with radical cystectomy. Int Urol Nephrol. 2008;40(2):321-7.

47. Koga F, et al. ErbB2 and NFkB overexpression as predictors of chemoradiation resistance and putative targets to overcome resistance in muscle-invasive bladder cancer. PLoS One. 2011;6(11):e27616.

48. Inoue $\mathrm{M}$, et al. Significance of ERBB2 overexpression in therapeutic resistance and cancer-specific survival in muscle-invasive bladder cancer patients treated with chemoradiation-based selective bladder-sparing approach. Int J Radiat Oncol Biol Phys. 2014;90(2):303-11.

49. Sasaki Y, et al. HER2 protein overexpression and gene amplification in upper urinary tract urothelial carcinoma-an analysis of 171 patients. Int J Clin Exp Pathol. 2014;7(2):699.

50. Kim B, et al. HER2 protein overexpression and gene amplification in plasmacytoid urothelial carcinoma of the urinary bladder. Dis Markers. 2016;2016:1.

51. Memon AA, et al. Expression of HER3, HER4 and their ligand heregulin-4 is associated with better survival in bladder cancer patients. Br J Cancer. 2004; 91(12):2034-41

52. Gunes $\mathrm{S}$, et al. ErbB receptor tyrosine kinase family expression levels in urothelial bladder carcinoma. Pathol Res Pract. 2013;209(2):99-104.

53. Turkeri $L N$, et al. Impact of the expression of epidermal growth factor, transforming growth factor alpha, and epidermal growth factor receptor on the prognosis of superficial bladder cancer. Urology. 1998;51(4):645-9.

54. Popov Z, et al. Prognostic value of EGF receptor and tumor cell proliferation in bladder cancer: therapeutic implications. In: Urologic oncology: seminars and original investigations; 2004. Elsevier.

55. Arfaoui AT, et al. Prognostic value of immunohistochemical expression profile of epidermal growth factor receptor in urothelial bladder cancer. J Immunoass Immunochem. 2016;37(4):359-67.

56. Berger $\mathrm{M}$, et al. Evaluation of epidermal growth factor receptors in bladder tumours. Br J Cancer. 1987;56(5):533-7.

57. Khaled HM, et al. Clinical significance of altered nm23-H1, EGFR, RB and p53 expression in bilharzial bladder cancer. BMC Cancer. 2009;9(1):32.

58. Lipponen $\mathrm{P}$, Eskelinen $\mathrm{M}$. Expression of epidermal growth factor receptor in bladder cancer as related to established prognostic factors, oncoprotein (c-erb B-2, p53) expression and long-term prognosis. Br J Cancer. 1994;69(6):1120-5.

59. Memon AA, et al. The relation between survival and expression of HER1 and HER2 depends on the expression of HER3 and HER4: a study in bladder cancer patients. Br J Cancer. 2006;94(11):1703-9.

60. Kim W, et al. S100A9 and EGFR gene signatures predict disease progression in muscle invasive bladder cancer patients after chemotherapy. Ann Oncol. 2014;25(5):974-9.

61. Colquhoun A, et al. Epidermal growth factor receptor status predicts local response to radical radiotherapy in muscle-invasive bladder cancer. Clin Oncol. 2006;18(9):702-9.

62. Thøgersen $\mathrm{V}$, et al. Expression of transforming growth factor alpha and epidermal growth factor receptor in human bladder cancer. Scand J Clin Lab Invest. 1999;59(4):267-77. 
63. Mansour AM, et al. Epidermal growth factor expression as a predictor of chemotherapeutic resistance in muscle-invasive bladder cancer. BMC Urol. 2018;18(1):100

64. Bryan RT, et al. Protein shedding in urothelial bladder cancer: prognostic implications of soluble urinary EGFR and EpCAM. Br J Cancer. 2015;112(6):1052-8.

65. Chu H, et al. EGFR 3' UTR 774T> C polymorphism contributes to bladder cancer risk. Mutagenesis. 2013;28(1):49-55.

66. Mason RA, et al. EGFR pathway polymorphisms and bladder cancer susceptibility and prognosis. Carcinogenesis. 2009;30(7):1155-60.

67. Li J, et al. Comparison of tyrosine kinase receptors HER2, EGFR, and VEGFR expression in micropapillary urothelial carcinoma with invasive urothelial carcinoma. Target Oncol. 2015;10(3):355-63.

68. Rajjayabun $\mathrm{PH}$, et al. erbB receptor expression patterns in human bladder cancer. Urology. 2005;66(1):196-200.

69. Imai T, et al. Significance of epidermal growth factor receptor and c-erb B-2 protein expression in transitional cell cancer of the upper urinary tract for tumour recurrence at the urinary bladder. Br J Cancer. 1995;71(1):69-72.

70. Li W, et al. Overexpression of epidermal growth factor receptor (EGFR) and HER-2 in bladder carcinoma and its association with patients' clinical features. Med Sci Monit. 2018;24:7178.

71. Kassouf $W$, et al. Distinctive expression pattern of ErbB family receptors signifies an aggressive variant of bladder cancer. J Urol. 2008;179(1):353-8.

72. Gonzalez-Roibon N, et al. Insulin-like growth factor-1 receptor overexpression is associated with outcome in invasive urothelial carcinoma of urinary bladder: a retrospective study of patients treated using radical cystectomy. Urology. 2014;83(6):1444.e1-6.

73. Rochester MA, et al. The type 1 insulin-like growth factor receptor is overexpressed in bladder cancer. BJU Int. 2007;100(6):1396-401.

74. Metalli $D$, et al. The insulin-like growth factor receptor I promotes motility and invasion of bladder cancer cells through Akt- and mitogen-activated protein kinase-dependent activation of paxillin. Am J Pathol. 2010;176(6): 2997-3006.

75. lozzo RV, Schaefer L. Proteoglycans in health and disease: novel regulatory signaling mechanisms evoked by the small leucine-rich proteoglycans. FEBS J. 2010;277(19):3864-75.

76. Marzioni D, et al. Expression of basic fibroblast growth factor, its receptors and syndecans in bladder cancer. Int J Immunopathol Pharmacol. 2009; 22(3):627-38.

77. Duenas M, et al. PIK3CA gene alterations in bladder cancer are frequent and associate with reduced recurrence in non-muscle invasive tumors. Mol Carcinog. 2015;54(7):566-76.

78. Juanpere $\mathrm{N}$, et al. Mutations in FGFR3 and PIK3CA, singly or combined with RAS and AKT1, are associated with AKT but not with MAPK pathway activation in urothelial bladder cancer. Hum Pathol. 2012;43(10):1573-82

79. Kompier LC, et al. FGFR3, HRAS, KRAS, NRAS and PIK3CA mutations in bladder cancer and their potential as biomarkers for surveillance and therapy. PLoS One. 2010;5:11.

80. Pandith AA, et al. Oncogenic activation of fibroblast growth factor receptor3 and RAS genes as non-overlapping mutual exclusive events in urinary bladder cancer. Asian Pac J Cancer Prev. 2016;17(6):2787-93.

81. Bertz $\mathrm{S}$, et al. Increased angiogenesis and FGFR protein expression indicate a favourable prognosis in bladder cancer. Virchows Arch. 2014;465(6):68795.

82. Billerey $C$, et al. Frequent FGFR3 mutations in papillary non-invasive bladder (pTa) tumors. Am J Pathol. 2001;158(6):1955-9.

83. van Oers JM, et al. FGFR3 mutations and a normal CK20 staining pattern define low-grade noninvasive urothelial bladder tumours. Eur Urol. 2007; 52(3):760-8.

84. van Oers JM, et al. FGFR3 mutations indicate better survival in invasive upper urinary tract and bladder tumours. Eur Urol. 2009;55(3):650-7.

85. Mhawech-Fauceglia P, et al. FGFR3 and p53 protein expressions in patients with pTa and pT1 urothelial bladder cancer. Eur J Surg Oncol (EJSO). 2006; 32(2):231-7.

86. Breyer J, et al. High CDKN2A/p16 and low FGFR3 expression predict progressive potential of stage pT1 urothelial bladder carcinoma. Clin Genitourin Cancer. 2018;16(4):248-256. e2.

87. Bodoor $\mathrm{K}$, et al. FGFR3 mutational status and protein expression in patients with bladder cancer in a Jordanian population. Cancer Epidemiol. 2010; 34(6):724-32.

88. Pedregosa AB, et al. Expresión de las proteínas FGFR3, PI3K, AKT, p21Waf1/ Cip1 y ciclinas D1 y D3 en pacientes con tumores de vejiga T1: implicaciones clínicas y significado pronóstico. Actas Urol Esp. 2017;41(3): $172-80$

89. Yang $Z$, et al. Somatic FGFR3 mutations distinguish a subgroup of muscleinvasive bladder cancers with response to neoadjuvant chemotherapy. EBioMedicine. 2018;35:198-203.

90. Abdul-Maksoud RS, et al. Fibroblast growth factor receptor 1 and cytokeratin 20 expressions and their relation to prognostic variables in bladder cancer. Gene. 2016;591(2):320-6.

91. McNeil BK, et al. Preliminary evaluation of urinary soluble met as a biomarker for urothelial carcinoma of the bladder. J Transl Med. 2014;12(1): 199.

92. Kim Y-W, et al. The c-MET network as novel prognostic marker for predicting bladder cancer patients with an increased risk of developing aggressive disease. PLoS One. 2015;10(7):e0134552.

93. Cheng $\mathrm{H}-\mathrm{L}$, et al. Co-expression of RON and MET is a prognostic indicator for patients with transitional-cell carcinoma of the bladder. Br J Cancer. 2005;92(10):1906-14.

94. Abraham S, et al. Expression of EphA2 and Ephrin A-1 in carcinoma of the urinary bladder. Clin Cancer Res. 2006;12(2):353-60.

95. Xia G, et al. EphB4 receptor tyrosine kinase is expressed in bladder cancer and provides signals for cell survival. Oncogene. 2006;25(5):769-80.

96. Xie $X$, et al. Discoidin domain receptor 1 activity drives an aggressive phenotype in bladder cancer. Am J Transl Res. 2017;9(5):2500-7.

97. Tsai MC, et al. DDR2 overexpression in urothelial carcinoma indicates an unfavorable prognosis: a large cohort study. Oncotarget. 2016;7(48):7891831.

98. Lai PC, Chiu TH, Huang YT. Overexpression of BDNF and TrkB in human bladder cancer specimens. Oncol Rep. 2010;24(5):1265-70.

99. Pan $C-X$, et al. C-kit expression in small cell carcinoma of the urinary bladder: prognostic and therapeutic implications. Mod Pathol. 2005;18(3): 320-3.

100. Shams TM, Metawea M, Salim El. C-KIT positive Schistosomal urinary bladder carcinomas are frequent but lack KIT gene mutations. Asian Pac J Cancer Prev. 2013;14(1):15-20.

101. Asai A, et al. Pathological significance and prognostic significance of FES expression in bladder cancer vary according to tumor grade. J Cancer Res Clin Oncol. 2018;144(1):21-31.

102. Nomura S, et al. Dual-specificity tyrosine phosphorylation-regulated kinase 2 (DYRK2) as a novel marker in T1 high-grade and T2 bladder cancer patients receiving neoadjuvant chemotherapy. BMC Urol. 2015;15(1):53.

103. Guo S, et al. Tyrosine kinase ETK/BMX is up-regulated in bladder cancer and predicts poor prognosis in patients with cystectomy. PLoS One. 2011;6(3): e17778.

104. Hynes NE, Lane HA. Myc and mammary cancer: Myc is a downstream effector of the ErbB2 receptor tyrosine kinase. J Mammary Gland Biol Neoplasia. 2001;6(1):141-50.

105. Hudis CA. Trastuzumab-mechanism of action and use in clinical practice N Engl J Med. 2007;357(1):39-51.

106. Coombs LM, et al. Amplification and over-expression of c-erbB-2 in transitional cell carcinoma of the urinary bladder. Br J Cancer. 1991;63(4): $601-8$.

107. Sato K, et al. An immunohistologic evaluation of C-erbB-2 gene product in patients with urinary bladder carcinoma. Cancer. 1992;70(10):2493-8.

108. Wolff AC, et al. Recommendations for human epidermal growth factor receptor 2 testing in breast cancer: American Society of Clinical Oncology/ College of American Pathologists clinical practice guideline update. J Clin Oncol. 2014;138(2):241-56.

109. Reznikoff CA, et al. Genetic alterations and biological pathways in human bladder cancer pathogenesis. In: Urologic oncology: seminars and original investigations; 2000. Elsevier.

110. Mellon JK, et al. C-erbB-2 in bladder cancer: molecular biology, correlation with epidermal growth factor receptors and prognostic value. J Urol. 1996; 155(1):321-6.

111. Miyamoto $\mathrm{H}$, et al. C-ERBB-2 gene amplification as a prognostic marker in human bladder cancer. Urology. 2000;55(5):679-83.

112. Moriyama $M$, et al. Expression of c-erbB-2 gene product in urinary bladder cancer. J Urol. 1991;145(2):423-7.

113. Sauter $G$, et al. Heterogeneity of erbB-2 gene amplification in bladder cancer. Cancer Res. 1993;53(10):2199-203.

114. Underwood $\mathrm{M}$, et al. C-erbB-2 gene amplification: a molecular marker in recurrent bladder tumors? Cancer Res. 1995;55(11):2422-30. 
115. Fleischmann A, et al. Extracapsular extension of pelvic lymph node metastases from urothelial carcinoma of the bladder is an independent prognostic factor. J Clin Oncol. 2005;23(10):2358-65.

116. Stein JP, et al. Radical cystectomy in the treatment of invasive bladder cancer: long-term results in 1,054 patients. J Clin Oncol. 2001;19(3):666-75.

117. Garcia JA, Dreicer R. Systemic chemotherapy for advanced bladder cancer: update and controversies. J Clin Oncol. 2006;24(35):5545-51.

118. Marín ÁP, et al. Role of anti-her-2 therapy in bladder carcinoma. J Cancer Res Clin Oncol. 2010;136(12):1915-20.

119. Grube $\mathrm{S}$, et al. Overexpression of fatty acid synthase in human gliomas correlates with the WHO tumor grade and inhibition with orlistat reduces cell viability and triggers apoptosis. J Neuro-Oncol. 2014;118(2): 277-87.

120. Jensen-Urstad AP, et al. Nutrient-dependent phosphorylation channels lipid synthesis to regulate PPARa. J Lipid Res. 2013;54(7):1848-59.

121. Lopez-Beltran A, et al. Plasmacytoid urothelial carcinoma of the bladder. Hum Pathol. 2009;40(7):1023-8.

122. Ro JY, et al. Plasmacytoid transitional cell carcinoma of urinary bladder: a clinicopathologic study of 9 cases. Am J Surg Pathol. 2008;32(5):752-7.

123. Burden S, Yarden Y. Neuregulins and their receptors: a versatile signaling module in organogenesis and oncogenesis. Neuron. 1997;18(6):847-55.

124. Le X-F, et al. Anti-HER2 antibody and heregulin suppress growth of HER2overexpressing human breast cancer cells through different mechanisms. Clin Cancer Res. 2000;6(1):260-70.

125. Le X-F, Varela C, Bast R. Heregulin-induced apoptosis. Apoptosis. 2002;7(6): 483-91.

126. Olayioye MA, et al. The ErbB signaling network: receptor heterodimerization in development and cancer. EMBO J. 2000;19(13):3159-67.

127. Yarden Y, Sliwkowski MX. Untangling the ErbB signalling network. Nat Rev Mol Cell Biol. 2001;2(2):127-37.

128. Tzahar $E$, et al. Bivalence of EGF-like ligands drives the ErbB signaling network. EMBO J. 1997;16(16):4938-50.

129. Pinkas-Kramarski R, et al. Diversification of Neu differentiation factor and epidermal growth factor signaling by combinatorial receptor interactions. EMBO J. 1996;15(10):2452-67.

130. Guy PM, et al. Insect cell-expressed p180erbB3 possesses an impaired tyrosine kinase activity. Proc Natl Acad Sci U S A. 1994;91(17):8132-6.

131. Rosenberg JE, Carroll PR, Small EJ. Update on chemotherapy for advanced bladder cancer. J Urol. 2005;174(1):14-20.

132. Sternberg C. The treatment of advanced bladder cancer. Ann Oncol. 1995; 6(2):113-26

133. Saxman SB, et al. Long-term follow-up of a phase III intergroup study of cisplatin alone or in combination with methotrexate, vinblastine, and doxorubicin in patients with metastatic urothelial carcinoma: a cooperative group study. J Clin Oncol. 1997;15(7):2564-9.

134. von der Maase $\mathrm{H}$, et al. Long-term survival results of a randomized trial comparing gemcitabine plus cisplatin, with methotrexate, vinblastine, doxorubicin, plus cisplatin in patients with bladder cancer. J Clin Oncol. 2005;23(21):4602-8.

135. Amin MB, et al. Micropapillary variant of transitional cell carcinoma of the urinary bladder. Histologic pattern resembling ovarian papillary serous carcinoma. Am J Surg Pathol. 1994;18(12):1224-32.

136. Lipponen PK. Expression of c-myc protein is related to cell proliferation and expression of growth factor receptors in transitional cell bladder cancer. J Pathol. 1995:175(2):203-10.

137. Le Roith D. Regulation of proliferation and apoptosis by the insulin-like growth factor I receptor. Growth Hormon IGF Res. 2000;10:S12-3.

138. Theocharis $A D$, et al. Proteoglycans in health and disease: novel roles for proteoglycans in malignancy and their pharmacological targeting. FEBS J. 2010;277(19):3904-23.

139. Iozzo RV, et al. Decorin antagonizes IGF receptor I (IGF-IR) function by interfering with IGF-IR activity and attenuating downstream signaling. J Biol Chem. 2011;286(40):34712-21.

140. Knowles MA, et al. Phosphatidylinositol 3-kinase (PI3K) pathway activation in bladder cancer. Cancer Metastasis Rev. 2009;28(3-4):305-16.

141. Platt FM, et al. Spectrum of phosphatidylinositol 3-kinase pathway gene alterations in bladder cancer. Clin Cancer Res. 2009;15(19):6008-17.

142. Cantley LCJS. The phosphoinositide 3-kinase pathway. Science. 2002; 296(5573):1655-7.

143. van Rhijn BW, et al. Frequent FGFR3 mutations in urothelial papilloma. J Pathol. 2002;198(2):245-51.
144. van Rhijn BW, et al. Molecular grading of urothelial cell carcinoma with fibroblast growth factor receptor 3 and MIB-1 is superior to pathologic grade for the prediction of clinical outcome. J Clin Oncol. 2003;21(10): 1912-21.

145. Hernández S, et al. FGFR3 and Tp53 mutations in T1G3 transitional bladder carcinomas: independent distribution and lack of association with prognosis. Clin Cancer Res. 2005;11(15):5444-50

146. Zieger $\mathrm{K}$, et al. Role of activating fibroblast growth factor receptor 3 mutations in the development of bladder tumors. Clin Cancer Res. 2005; 11(21):7709-19.

147. Horton WA, Garofalo S, Lunstrum GP. FGFR3 signaling in achondroplasia: a review. Cell Mater. 1998;8:83-7.

148. L'Hôte CG, Knowles MA. Cell responses to FGFR3 signalling: growth differentiation and apoptosis. Exp Cell Res. 2005;304(2):417-31.

149. Powers C, McLeskey S, Wellstein A. Fibroblast growth factors, their receptors and signaling. Endocr Relat Cancer. 2000;7(3):165-97.

150. Siegel R, Naishadham D, Jemal A. Cancer statistics, 2012. CA Cancer J Clin. 2012;62(1):10-29.

151. Roberts JT, et al. Long-term survival results of a randomized trial comparing gemcitabine/cisplatin and methotrexate/vinblastine/doxorubicin/cisplatin in patients with locally advanced and metastatic bladder cancer. Ann Oncol. 2006;17(suppl_5):v118-22.

152. Cecchi F, Rabe DC, Bottaro DP. Targeting the HGF/met signaling pathway in cancer therapy. Expert Opin Ther Targets. 2012;16(6):553-72.

153. Ciardiello F. EGFR antagonists in cancer treatment. N Engl J Med. 2008; 358(11):1160-74

154. Noon AP, Catto JWF. Challenging current paradigms. Nat Rev Urol. 2013; 10(2):67-8.

155. Peters S, Adjei AA. MET: a promising anticancer therapeutic target. Nat Rev Clin Oncol. 2012;9(6):314

156. Miyata Y, et al. Phosphorylated hepatocyte growth factor receptor/c-met is associated with tumor growth and prognosis in patients with bladder cancer: correlation with matrix metalloproteinase-2 and-7 and E-cadherin. Hum Pathol. 2009:40(4):496-504.

157. Yeh C-Y, et al. Transcriptional activation of the Axl and PDGFR-a by c-met through a ras-and $\mathrm{Src}-$ independent mechanism in human bladder cancer. BMC Cancer. 2011;11(1):139.

158. Ronsin C, et al. A novel putative receptor protein tyrosine kinase of the met family. Oncogene. 1993;8(5):1195-202.

159. Dodelet VC, Pasquale EB. Eph receptors and ephrin ligands: embryogenesis to tumorigenesis. Oncogene. 2000;19(49):5614-9.

160. Pasquale EB. The Eph family of receptors. Curr Opin Cell Biol. 1997;9(5):60815

161. Gerety SS, et al. Symmetrical mutant phenotypes of the receptor EphB4 and its specific transmembrane ligand ephrin-B2 in cardiovascular development. Mol Cell. 1999;4(3):403-14.

162. Holder N, Klein R. Eph receptors and ephrins: effectors of morphogenesis. Development. 1999;126(10):2033-44.

163. Tickle C, Altabef M. Epithelial cell movements and interactions in limb, neural crest and vasculature. Development. 1999;9(4):455-60.

164. Andres $A C$, et al. Protein tyrosine kinase expression during the estrous cycle and carcinogenesis of the mammary gland. Int J Cancer. 1995;63(2):288-96.

165. Berclaz G, et al. Expression of the receptor protein tyrosine Kinasemyk-1/ htkin Normal and malignant mammary epithelium. Biochem Biophys Res Commun. 1996:226(3):869-75.

166. Stephenson S-A, et al. Receptor protein tyrosine kinase EphB4 is upregulated in colon cancer. BMC Mol Biol. 2001;2(1):15.

167. Takai N, et al. Expression of receptor tyrosine kinase EphB4 and its ligand ephrin-B2 is associated with malignant potential in endometrial cancer. Oncol Rep. 2001;8(3):567-73.

168. Adams RH, et al. Roles of ephrinB ligands and EphB receptors in cardiovascular development: demarcation of arterial/venous domains, vascular morphogenesis, and sprouting angiogenesis. Genes Dev. 1999; 13(3):295-306.

169. O'Leary DD, Wilkinson DG. Eph receptors and ephrins in neural development. Curr Opin Neurobiol. 1999;9(1):65-73.

170. Oates $A C$, et al. An early developmental role for eph-ephrin interaction during vertebrate gastrulation. Mech Dev. 1999:83(1-2):77-94.

171. Steinle JJ, et al. Eph B4 receptor signaling mediates endothelial cell migration and proliferation via the phosphatidylinositol 3-kinase pathway. J Biol Chem. 2002;277(46):43830-5. 
172. Vogel W. Discoidin domain receptors: structural relations and functional implications. FASEB J. 1999;13(Suppl):S77-82.

173. Suh HN, Han HJ. Collagen I regulates the self-renewal of mouse embryonic stem cells through alpha2beta1 integrin- and DDR1-dependent Bmi-1. J Cell Physiol. 2011;226(12):3422-32.

174. Yeh YC, Wang CZ, Tang MJ. Discoidin domain receptor 1 activation suppresses alpha2beta1 integrin-dependent cell spreading through inhibition of Cde42 activity. J Cell Physiol. 2009;218(1):146-56.

175. Huo Y, et al. High expression of DDR1 is associated with the poor prognosis in Chinese patients with pancreatic ductal adenocarcinoma. J Exp Clin Cancer Res. 2015;34:88.

176. Ikeda K, et al. Discoidin domain receptor 2 interacts with Src and Shc following its activation by type I collagen. J Biol Chem. 2002;277(21): 19206-12.

177. Huang EJ, Reichardt LF. Neurotrophins: roles in neuronal development and function. Annu Rev Neurosci. 2001;24(1):677-736.

178. Miknyoczki SJ, et al. Neurotrophins and Trk receptors in human pancreatic ductal adenocarcinoma: expression patterns and effects on in vitro invasive behavior. Int J Cancer. 1999;81(3):417-27.

179. Montano X, Djamgoz MBA. Epidermal growth factor, neurotrophins and the metastatic cascade in prostate cancer. FEBS Lett. 2004:571(1-3):1-8.

180. Ricci A, et al. Neurotrophins and neurotrophin receptors in human lung cancer. Am J Respir Cell Mol Biol. 2001;25(4):439-46.

181. Natali PG, et al. Expression of c-kit receptor in normal and transformed human nonlymphoid tissues. Cancer Res. 1992;52(22):6139-43.

182. Pietsch T, et al. Expression of the c-kit receptor and its ligand SCF in nonsmall-cell lung carcinomas. Int J Cancer. 1998;75(2):171-5.

183. Demetri GD. Targeting c-kit mutations in solid tumors: scientific rationale and novel therapeutic options. In: Seminars in oncology; 2001. Elsevier

184. Potti A, et al. CD117 (c-KIT) overexpression in patients with extensive-stage small-cell lung carcinoma. Ann Oncol. 2003;14(6):894-7.

185. DiPaola RS, et al. Evidence for a functional kit receptor in melanoma, breast, and lung carcinoma cells. Cancer Gene Ther. 1997;4(3):176-82.

186. Yarden Y, et al. Human proto-oncogene c-kit: a new cell surface receptor tyrosine kinase for an unidentified ligand. EMBO J. 1987;6(11):3341-51.

187. Zsebo KM, et al. Stem cell factor is encoded at the SI locus of the mouse and is the ligand for the c-kit tyrosine kinase receptor. Cell. 1990;63(1):213-24

188. Tsuura $Y$, et al. Preferential localization of $\mathrm{c}$-kit product in tissue mast cells, basal cells of skin, epithelial cells of breast, small cell lung carcinoma and seminoma/dysgerminoma in human: immunohistochemical study on formalin-fixed, paraffin-embedded tissues. Virchows Arch. 1994;424(2):135-41.

189. Greer PJNRMCB. Closing in on the biological functions of $\mathrm{fps} / \mathrm{Fes}$ and Fer. Nat Rev Mol Cell Biol. 2002;3(4):278-89.

190. Kanda S, et al. Downregulation of the c-Fes protein-tyrosine kinase inhibits the proliferation of human renal carcinoma cells. Int J Oncol. 2009;34(1):89-96.

191. Miyata Y, et al. Pathological significance and predictive value for biochemical recurrence of c-Fes expression in prostate cancer. Prostate. 2012:72(2):201-8.

192. Campbell LE, Proud CG. Differing substrate specificities of members of the DYRK family of arginine-directed protein kinases. FEBS Lett. 2002; 510(1-2):31-6.

193. HIMPEL S, et al. Identification of the autophosphorylation sites and characterization of their effects in the protein kinase DYRK1A. Biochem J. 2001;359(3):497-505.

194. Becker W, Joost H-G. Structural and functional characteristics of Dyrk, a novel subfamily of protein kinases with dual specificity, in Progress in nucleic acid research and molecular biology. Prog Nucleic Acid Res Mol Biol. 1998;62:1-17.

195. Aranda S, Laguna A, de la Luna S. DYRK family of protein kinases: evolutionary relationships, biochemical properties, and functional roles. FASEB J. 2011;25(2):449-62

196. Park J, et al. Function and regulation of Dyrk1A: towards understanding Down syndrome. Cell Mol Life Sci. 2009;66(20):3235-40

197. Taira N, et al. DYRK2 is targeted to the nucleus and controls p53 via Ser46 phosphorylation in the apoptotic response to DNA damage. Mol Cell. 2007; 25(5):725-38.

198. Qiu Y, Kung HJ. Signaling network of the Btk family kinases. Oncogene. 2000;19(49):5651-61.

\section{Publisher's Note}

Springer Nature remains neutral with regard to jurisdictional claims in published maps and institutional affiliations.

\section{Ready to submit your research? Choose BMC and benefit from:}

- fast, convenient online submission

- thorough peer review by experienced researchers in your field

- rapid publication on acceptance

- support for research data, including large and complex data types

- gold Open Access which fosters wider collaboration and increased citations

- maximum visibility for your research: over $100 \mathrm{M}$ website views per year

At BMC, research is always in progress.

Learn more biomedcentral.com/submissions 